\title{
International Geological Congress Moscow, August 1984
}

(C. - Themes. S. - Intersectional Symposia. S.S. -Special Symposium). Conveners listed for main sections. Co-sponsors listed in brackets ( ).

\section{A. PLENARY SESSIONS}

OPENING SESSION (August 5)

RECENT ACHIEVEMENTS IN GEOLOGY E. Seibold (F.R.G.) and V.V. Menner (U.S.S.R.)

Ye.A. Kozlovsky (U.S.S.R.): Geology in the national economy of the U.S.S.R.

W. Hay (U.S.A.): The past and future of scientific ocean drilling.

V.L. Barsukov (U.S.5.R.) and H. Masursky (U.S.A.) Comparative planetology in earth history studies.

R.A. Price (Canada): Dynarnics and evolution of the lithosphere: the framework for earth resources and the reduction of hazards.

A.L. Yanhsin (U.S.S.R.): Evolution of geological processes in earth history.

M.T. Halbouty (U.S.A.): Basins of the world and new frontiers.

CLOSING SESSION (August 14)

GEOLOGICAL ASPECTS OF ENVIRONMENTAL PROTECTION

Ye.A. Kozlovsky (U.S.S.R) and M. Tolba (Kenya)

Ye.A. Kozlovsky (U.S.S.R.): Geological aspects of environmental protection.

G. Castany (France): Impacts des projets de développement des ressources en eau sur l'environnement.

G. Lüttig (F.R.G.): Influence of mining activities on the environment.

E.M. Sergeev (U.S.S.R.): Advance in science and technology and the environment.

M. Suk and J. Vrba (Czechoslovakia): Integrated use of natural resources and geoenvironment.

L. Konnigsson (Sweden): The management of the environment and its background in natural history.

\section{B. TECHNICAL SECTIONS}

C.01. STRATIGRAPHY. (ICS) M.G. Bassett (U.K.), I. Chlupac (Czechoslovakia), A.I. Zhamoida (U.S.S.R.)

C.01.1.I. Principles and Methods of Stratigraphy. Stratigraphy and Geochronology.

C.01.1.2. Limits of Precision and Geographic Stability of Stratigraphic Units.

C.01.1.3. Nature and Types of Stratigraphic Boundaries. (IGCP 153)

C.01.1.4. Problems of Phanerozoic Stratigraphy.

5.01.2.1. Correlation of Sediments Belonging to Different Facies and Biogeographic Provinces.

5.01.2.2. Vendian (Terminal System of Precambrian) and the Precambrian-Phanerozoic Boundary. (IGCP 29)

5.01.2.3. Permian System.

S.01.2.4. Palynos tratigraphy.

C.02. PALAEONTOLOGY. (IPA)

A. Yu Rozanoy (U.S.S.R.), O.H. Walliser (F.R.G.).

C.02.1.1. Early Stages of Organic Life.

C.02.1.2. Palaeoecology and Evolution of Ecological Systems.

C.02.1.3. Origin and Distribution of Vertebrates, Including Early Tetrapods.

C.02.1.4. Architectonics and Constructional Mor- phology as a Key to the Analysis of Phylogeny.

C.02.1.5. Microstructural and Chemical Aspects of Fossils.

S.02.2.1. Fundamental Biotic Changes in the Earth's History and Extinction of Fossil Groups.

S.02.2.2. Stromatolites, Stromatolitic Microbiotas and Calcareous Algae in the Earth's His. tory.

S.02.2.3. Cancelled

S.02.2.4. Evolution, Migration and Provincialism of Cambrian Faunas and Floras.

\section{C.03. QUATERNARY GEOLOGY AND GEO-} MORPHOLOGY.

H. Faure (France), K.V. Nikiforova (U.S.S.R.).

C.03.1.1. Quaternary Chronostratigraphy of Eurasia. (IGCP 41)

C.03.1.2. Stratigraphy of Pliocene-Quaternary Sediments of Oceans and Seas.

C.03.1.3. Fluctuations of the Ocean Basins Level and Quaternary Palaeoclimates.

C.03.1.4. Geomorphology, Palaeogeomorphology and Neotectonics.

5.03.2.1. Regularity of Tectonic Movements during the Late Tertiary and Quaternary.

\section{C.04. SEDIMENTOLOGY}

K. Crook (Australia), P.P. Timofeev (U.S.S.R.)

C.04.1.1. Hypergenesis (Chemical and Physical Weathering) and Sedimentogenesis (sedimentation, including transportation and depositional processes).

C.04.1.2. Sedimentological Processes and their Controlling Factors.

C.04.1.3. Palaeogeographic and Facies Analysis. Facies models.

C.04.1.4. The Role of Climate in Sedimentation and Sedimentary Processes.

C.04.1.5. Carbonate and Halogenic Deposits. (IAS)

S.04.2.1. Sedimentation and Geotectonic Regimes.

S.04.2.2. Evolution of Sedimentary Ore Deposits.

C.05. PRECAMBRIAN GEOLOGY

H.L. James (U.S.A.), Veumann (D.D.R.), N.P. Shcherbak (U.S.S.R.)

C.05.1.1. Principles of Precambrian Stratigraphy and the Main Subdivisions of the Precambrian. Isotopic Geochronology of the Precambrian.

C.05.1.2. Archaean Sedimentation and the Archaean Proterozoic Boundary. (IGCP 160)

C.05.1.3. Life and Organic Matter in the Precambrian. Origin of the Atmosphere and $\mathrm{Hy}$ drosphere. (IGCP $157 \& 160$ )

C.05.1.4. Principles of Proterozoic Stratigraphy.

S.05.2.1. Precambrian Metallogeny. (IGCP 91)

S.05.2.2. Early Stages of Lithosphere Evolution. (IGCP 160)

S.05.2.3. Fold Belts and Plate Tectonics in the Precambrian. (ILP-WG 3)

\section{C.06. GEOLOGY OF OCEAN BASINS.} W. Hey (U.S.A.), Yu.M. Pushcharovsky (U.S.S.R.)

C.06.1.1. Sedimentary Layers in Oceans and Seas: Formation and Structure.

C.06.1.2. Palaeoceanology.

C.06.1.3. Natural Laws Controlling the Distribution and Origin of Metalliferous Deposits and Ferromanganese Nodules.

C.06.1.4. Petrochemical and Geochemical Provinces of the Basaltic Layer of the Ocean.

c.06.1.5. Geophysical Studies of the World Ocean Floor: Methods and Results.

5.06.2.1. Global Stratigraphic Correlation of Mesozoic-Cenozoic Sediments of Oceans and Continents. (IGCP 183)

S.06.2.2. Correlation of Tectonic Events in Oceanic Areas and on Continental Margins During the Mesozoic and Cenozoic.

5.06.2.3. Origin and History of Marginal and Inland Seas. (IGCP 195 \& ILP-WG8)

C.07. TECTONICS.

A.V. Peyve (U.S.S.R.), R. Trümpy (Switzerland)

c.07.1.1. Principles of Tectonic Zonation of Continents.

C.07.1.2. Transition Zones between Continents and Oceans.

C.07.1.3. Tectonics of Continental Fold Belts. (IGCP 5 \& ILP-WG2)

c.07.1.4. Tectonic Stratification of the Lithosphere.

C.07.1.5. Continenta] and Oceanic Rift Systems.

C.07.1.6. Deformation Processes in Rocks.

S.07.2.1. Deep-seated Heterogeneities in the Structure of the Earth's Crust and their Tectonic Implications.

S.07.2.2. Tectonics of the North Pacific and its Framework.

C.08. GEOPHYSICS

V.V. Belousov (U.S.S.R.), St. Mülle (Switzerland), D.A. Valencio (Argentina).

C.08.1.1. Structure of the Earth's Crust and Lithosphere Based on DSS Data.

C.08.1.2. The Asthenosphere: Distribution, Characteristic Features, Nature.

C.08.1.3. Geophysical Fields, Nature and Geological Interpretation.

C.08.1.4. Seismicity; Relations with Geophysical Fields, Tectonics and Recent Movements; Earthquake Prediction.

C.08.1.5. Geophysics and Volcanism. Prediction of Volcanic Eruptions.

C.08.1.6. Applied Geophysics.

S.08.2.1. Palaeomagnetism and Tectonics.

\section{C.09. PETROLOGY (IGNEOUS AND META-} MORPHIC ROCKS)

O.A. Bogatikov (U.S.S.R.), 1. Kushiro (Japan).

C.09.1.1. Igneous, Metamorphic and Metasomatic Rocks as Indicators of the Earth's Deep Structure.

C.09.1.2. Comparative Characteristics of Oceanic and Continental Magmatic Rock Formations.

C.09.1.3. Evolution of Magmatic and Metamorphic Processes in the Earth and its Major Regions. (ILP-CC4)

C.09.1.4. Capacity of Ore-Deposit Production of Magmatic, Metamorphic and Metasomatic Rocks.

5.09.2.1. Origin and Evolution of Magmas.

5.09.2.2. Experimental Phase Equilibria Studies as Indicators of the Physico-Chemical Conditions of Magmatic, Metamorphic and Metasomatic Rock Formation.

5.09.2.3. Nature and Origin of Trondhjemites, Plagiogranites and Related Rocks.

\section{C.10. MINERALOGY}

F.V. Chukhrov (U.S.S.R.), S. Hafner (F.R.G.), I.N. Kostov (Bulgaria).

C.10.1.1. Typomorphism of Minerals.

C.10.1.2. New Data on the Crystal Chemistry of Minerals. 
C.10.1.3. Physics of Minerals.

S.10.2.1. Thermodynamics of Mineral Formation. (CEPHPT and IAGC)

S.10.2.2. Molten and Gas-Liquid Microinclusions in Mineral-Forming Substances.

\section{C.11. GEOCHEMISTRY AND COSMO}

\section{CHEMISTRY}

V.L. Barsukov (U.S.S.R.), M.H. Grünenfelder (Switzerland), B. Hitchon (Canada)

C.11.1.1. Geochemical Cycles and Natural Laws Governing the Distribution of Elements in the Earth's Crust.

C.11.1.2. Geochemistry of Ore-Forming Processes.

C.11.1.3. Geochemistry of Magmatic Processes.

C.11.1.4. Applied Geochemistry; Geochemical Ore Prospecting and Earthquake Prediction.

C.11.1.5. Isotope Geochemistry.

C.11.1.6. Origin and Evolution of Solar System.

C.11.1.7. Geochemistry of Extraterrestrial Matter.

C.11.1.8. Cancelled

S.11.2.1. Geochemistry, Composition and Structure of the Earth's Upper Mantle. (IAGC)

S.11.2.2. Geochemistry of Oil-Forming Processes. (IAGC)

S.11.2.3. Rare Gases and the Origin and History of the Earth and Other Planets. (IAGC)

\section{C.12. METALLOGENESIS}

N. Fisher (Australia), L. Kostelka (Austria), N.P. Laverov (U.S.S.R.)

C.12.1.1. Comparative Metallogenesis of the $\mathrm{Ar}$ chaean, Proterozoic and Phanerozoic.

c.12.1.2. Sources of Ore-Forming Substances.

C.12.1.3. Syngenetic and Epigenetic Stratiform Ore Deposits.

C.12.1.4. Regoliths and Mineral Resources.

5.12.2.1. Petrologic and Geochemical Aspects of Metallogenesis. (IGCP 197)

5.12.2.2. Geology and Geochemistry of Manganese and Associated Metals.

S.S.12.3.1. Geology and Conditions of Formation of Copper Deposits. (IAGOD, SEG, SGA)

S.S.12.3.2.Metallogenesis and Uranium Deposits (IAEA)

C.13. OLL AND GAS FIELDS

A.W. Bally (U.S.A.), F.N. Talukda (India), A.A. Trofimuk (U.S.S.R.)

C.13.1.1. Oil and Gas-Bearing Provinces of Continents. Recently Discovered OIl and Gas Bearing Regions.

C.13.1.2. Oil and Gas Potential of Submarine Continental Margins.

C.13.1.3. Oil and Gas Source Rocks, Stages of Oil and Gas Formation.

C.13.1.4. Methods of Quantitative Prediction of Hydrocarbons in Sedimentary Rocks; Phase States of Hydrocarbons.

C.13.1.5. Oil and Gas in Deep Zones of the Lithosphere.

5.13.2.1. Models of Prospecting for Oil and Gas. Methods of Long-Term Prognosis of Oil and Gas Prospecting and their Results.

S.13.2.2. Tectonic Control of Non-Magmatic Degassing Processes; Mud-Volcanism.

C.14. SOLID FUEL MINERAL DEPOSITS V.S. Borisov (U.S.S.R.), R. Feis (France)

C.14.1.1. The Formation and Metamorphism of Peat, Coal and Oil-Shale.

C.14.1.2. Tectonics of Coal and Oil-Shale Basins.

C.14.1.3. The Composition and Characteristics of Solid Fuel Minerals.

C.14.1.4. Minerals Associated with the Solid Fuels and Geological and Geochemical Aspects of their Study.

5.14.2.1. Cyclic Sediment Accumulation.

\section{C.15. NON-METALLIC MINERAL ORES.} P.J. Cook (Australia), G.E. Murray Petrov (U.S.S.R.)

C.15.1.1. New Types of Non-Metallic Raw Materials.

C.15.1.2. Phosphates, Phosphorites and Apatites; Genesis, Mineralogy and Distribution.
(IGCP 156)

C.15.1.3. Non-Metallic Minerals of Granitoids and Pegmatites.

C.15.1.4. Clays and Kaolins; Genesis, Mineralogy and Utilization.

C.15.1.5. Precious and Semi-Precious Stones: Genesis, Nature of Distribution. (IMA)

\section{C.16. HYDROGEOLOGY.}

G. Castany (France), G.V. Kulikov (U.S.S.R.)

C.16.1.1. Modern Theoretical Problems of Hydrogeology.

c.16.1.2. Forecasting Changes in Chemical Com position of Underground Water Reserves.

C.16.1.3. Methods of Modelling Hydrogeologica Processes.

C.16.1.4. Hydrogeological Problems in Optimum Underground Water Utilization and Control of Underground Water Regimes.

C.16.1.5. Ecological Consequences of Artificia Changes in the Hydrogeological Regime.

S.16.2.1. Hydrogeological and Engineering-Geological Studies Relative to Land Reclamation.

S.16.2.2. Trace-Element Geochemistry of Underground Drinking Water.

\section{C.17. ENGINEERING GEOLOGY.}

M. Arnould (France), M. Langer (F.R.G.), E.M. Sergeev (U.S.S.R.)

C.17.1.1. Theoretical Problems of Engineering $\mathrm{Ge}$ ology.

C.17.1.2. Engineering-Geological Fundamentals for the Rational Use and Protection of the Geological Environment.

C.17.1.3. Engineering-Geological Problems in Studying Rocks and their Properties.

c.17.1.4. The Quantitative and Temporal-Spatial Prediction of Development of Geological and Engineering-Geological Processes.

C.17.1.5. Regional Engineering Geology. Problems of Engineering-Geological Mapping and Zonation.

C.17.1.6. New Methods in Engineering-Geological Studies and Surveying.

S.17.2.1. Application of the Airborne and Satellite Methods in Engineering-Geological and Hydrogeological Mapping.

S.17.2.2. Engineering-Geological and Hydrogeological Studies Related to the Economic Development of Permafrost Regions.

\section{C.18. REMOTE SENSING.}

P. Bankwitz (D.D.R.), W.D. Carter (U.S.A.), N.V. Mezhelovsky (U.S.S.R.) V.M. Moralev (U.S.S.R.)

C.18.1.1. Application of Remote Sensing to Geological Mapping.

C.18.1.2. Spectral Measurement of Rocks from Ground, Aircraft and Spacecraft.

C.18.1.3. Remote Sensing and Prospecting for Mineral Resources. (IGCP 143)

C.18.1.4. Remote Sensing and Prospecting for Oil and Gas.

C.18.1.5. Application of Remote Sensing to the Study of Recent Geological Processes and Seismicity.

c.18.1.6. Origin and Significance of Ring Structures in the Structure of the Earth's Crust.

\section{c.19. COMPARATIVE PLANETOLOGY. M.S. Markov (U.S.S.R.), H. Mazursky} (U.S.A.), L. Silver (U.S.A.)

C.19.1.1. Geomorphology, Tectonics and Deep Structure of Terrestrial Planets and their Satellites.

C.19.1.2. Structure and Composition of the Giant Planets and their Satellites.

C.19.1.3. Astronomical Factors in the Earth's Evolution.

S.19.2.1. Origin and Evolution of Life on Earth. (IGCP 157)

\section{C.20. MATHEMATICAL GEOLOGY.}

D. Merriam (U.S.A.), D.A. Rodionov (U.S.S.R.), R. Sinding-Larsen (Norway)
C.20.1.1. Mathematical Models of Geological Pro cesses.

C.20.1.2. Mathematical Approaches to Geological Classification. (IGCP 148)

C.20.1.3. Geostatistics.

C.20.1.4. Mathematical Analysis of Geological Information Obtained from Space Images and Application to Geological Mapping.

S.20.2.1. Computer Evaluation and Prediction of Geological Resources.

5.20.2.2. Geological Information: Collection, Storage, Distribution and Management of Geological Data.

5.20.2.3. Quality and Quantity of the Jurassic Time Scale. (IGCP 148, 171 \& ICS)

C.21. HISTORY OF GEOLOGY.

R. Hooykaas (Netherlands), V.V. Tikhomirov (U.S.S.R.), T. Vallance (Australia)

C.21.1.1. Development of Concepts of the Earth's Composition.

C.21.1.2. Evolution of Concepts of the Dynamics and Structure of the Earth's Crust and Upper Mantle.

S.21.2.1. History of Mineralogy (INHIGEO \& IMA)

C.22. GEOLOGICAL EDUCATION.

D.E. Ajakaiye (Nigeria), V.E. Khain (U.S.S.R.), Ch. Pomerol (France)

C.22.1.1. Consideration of New Ideas Concerning the Structure and Evolution of the Earth's Crust and Lithosphere with Regard to Geological Education.

C.22.1.2. Co-Ordination between Disciplines of Geology, Geophysics and Geochemistry in Geological Education.

C.22.1.3. Relative Proportions of Theoretical and Practical Geological Training; Field, Geophysical and Drilling Practice.

S.22.2.1. Geological Education and Environmental Protection.

S.22.2.2. Geological Education in Developing Countries and Assistance by Developed Countries.

\section{COLLOQUIA}

K.01. GEOLOGY OF THE U.S.S.R.

L.I. Krasni (U.S.S.R.), V.M. Volkov (U.S.S.R.)

K.02. ENERGY RESOURCES OF THE WORLD. M. Halbouty (U.S.A.), R.W. Hutchison (Canada), R.F. Meyer (U.S.A.), R.A. Sumbatov (U.S.S.R.)

K.03. PALAEOCEANOGRAPHY. (CMG DSDP \& ILP-WG2, WG 3) K.J. Hsü (Switzerland), A.P. Lisitsin (U.S.S.R.)

K.04. ARCTIC GEOLOGY.

I.S. Gramberg (U.S.S.R.), J. Thiede (F.R.G.)

K.05. TECTONICS OF ASIA

T.K. Huang (China), A.L. Yanshin (U.S.S.R.)

K.06. EARTHQUAKE AND GEOLOGICAL HAZARD PREDICTION.

H. Berckhemer (Denmark), S.A. Fedotov (U.S.S.R.)

D. INTERNATIONAL LITHOSPHERE PROGRAMME - SPECIAL SESSION

R. Price (Canada), A.L. Yanshin (U.S.S.R.)

L.01. Evolution of Sedimentary Basins and

.02 their Mineral and Energy Resources.

.02. Circum-Pacific Orogenic Belts and Evo-

L.03. Archaean Lithosphere and Early Crustal

Recent and Quaternary Plate Motions.

L.05. Palaeoenvironmental Evolution of the Oceans and the Atmosphere.

L.06. Geochemical and Geophysical Modelling

Geological, Geophysical and Geochemical Constraints on the Deep Structure of the Continents and Ocean Basins.

L.08. Continental Drilling.

L.09. Groundwater Exploration and Development in Semi-Arid Zones.

L.10. Proterozoic Crustal Dynamics and Lithospheric Evolution. 
Announcing

A

Canadian - American Conference

On

Practical Applications of

Ground Water Geochemistry

\section{Presented Jointly BY}

The Alberta Research Council

And

\section{The National Water Well Association}

At

The Bantf Springs Hotel

High Atop The Canadian Roclies

June 22-26, 1984

\section{Fecturing}

Formal Lectures on Fundamental Aspects of Ground Water Geochemistry by:

Dr Jósef Tóth The University of Alberta

Dr Donald Iangmuir Colorado school of Mines

Dr Yousif Kharaka USGS, Menlo Park

Dr Niel Plummer, USGS Reston

Dr. Peter Fitz. Me University of Waterloo

Dr Brion Hitchon, Dr Ed Wallick, Mark Trudell, The Alberta Research Council

Dr Richard Knapp, Sohio, San Franctsco

In addition there will be numerous short presentations by dozens of other experts in the field, as well as workshops on the most thought-provoking aspects of ground vater geochemistry.

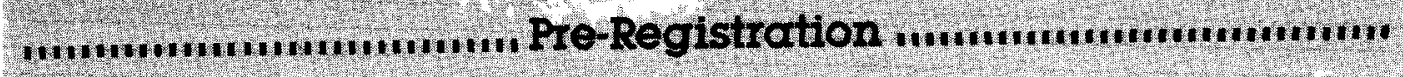

This conterence will be limited to 300 individuals A pre-registration fee of $\$ 25$ U.S. will guarantee your place in the conference. The full registration fee of $\$ 350$ U.S. will be payable on or betore May 15, 1984. A full refund of your pre-registration fee or complete registration will be honored belore May 15 After May 15, a service charge 01 \$25 US. will be retained. Complete and retum the form below.

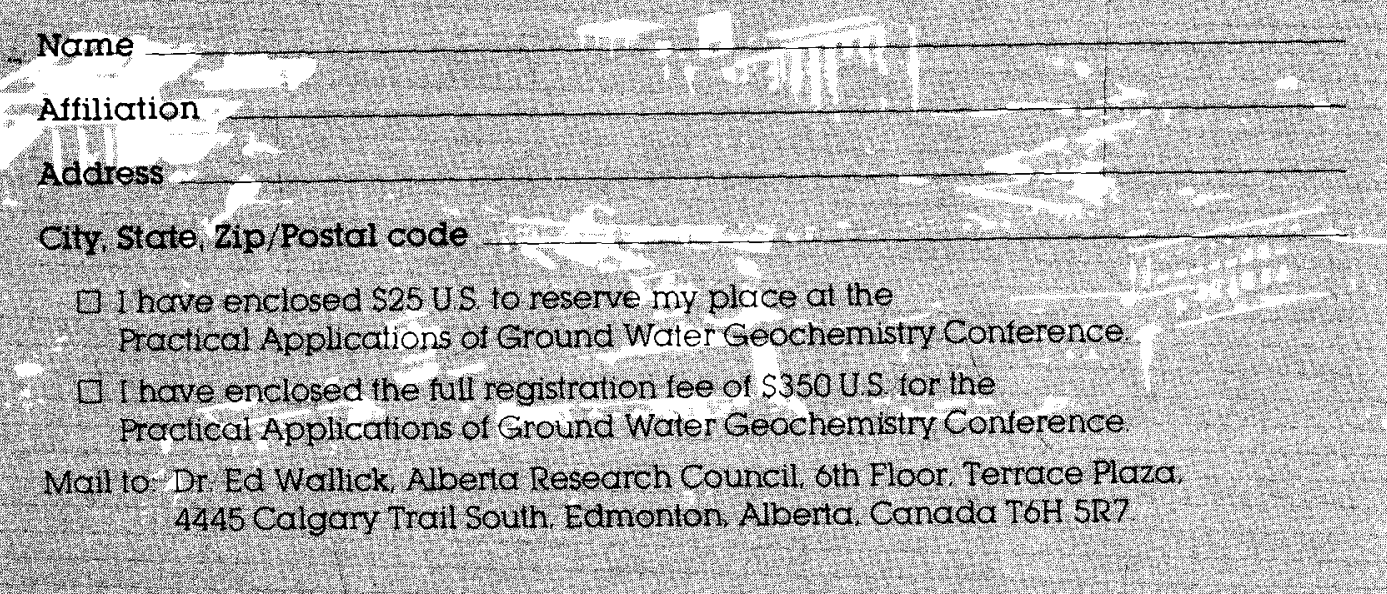




\section{CANADIAN SOCIETY OF PETROLEUM GEOLOGISTS}

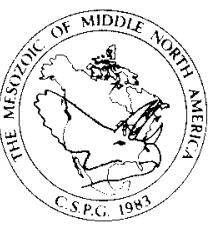

\section{Memoir 9 \\ THE MESOZOIC OF MIDDLE NORTH AMERICA}

Proceedings of CSPG conference held in

Calgary, Alberta, May 1983

The articles describe Mesozoic rocks in areas from the Beaufort Sea in the north to the San Juan Basin in the south.

They include reports on palynology, paleontology, sedimentology and economic geology.

Some of the 33 papers are:

Marine cycles - Lower Cretaceous Caldwell Lower Cretaceous Mannville Group, northern Williston Basin Christopher

Cretaceous alluvial deposits, southern Rocky Mountain basins Flores

Paleoecology and Paleoceanography, Greenhorn Eustatic Cycle . . . . . . Kauffman, Arthur \& Pratt Storm event sedimentation; Cardium

Formation, Pembina Oilfield Krause \& Nelson

Pembina - in retrospect . . . . . . . . . Nielsen and Porter

The Jurassic from $49^{\circ}$ to Beaufort Sea ......... Poulton

Hydrocarbon potential of low-

permeability Cretaceous sandstones Simpson

Regional paleogeography of the Early

Cretaceous seaway, southwestern Montana Vuke

\section{Edited by}

Donald F. Stott and Donald J. Glass

C.S.P.G. MEMOIR 9

Approximately 600 pages,

Hard cover, $21 \times 28 \mathrm{~cm}, 1984$

ISBN 0-920230-25-3

Send me @ \$38.00 each ${ }^{\star}$

Postpaid anywhere copies of Memoir 9

Name

Institution

\section{Address}

City Prov/State

Postal/Zip

* Send payment in Canadian Funds with order
Complete this form and send it with your payment to the Canadian Society of Petroleum Geologists at the address below

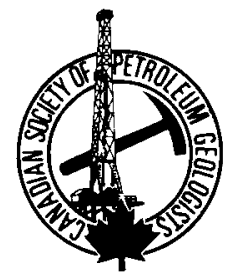

Canadian Society of Petroleum Geologists \#505, 206 - 7th Ave. S.W. Calgary, Alberta, Canada T2P 0W7 